\title{
A Crise dos Negócios do Diamante e as Respostas dos Homens de Fortuna no Alto Jequitinhonha, Décadas de 1870-1890
}

\author{
- Marcos lobato Martins*
}

\begin{abstract}
RESUMO
Este trabalho aborda a crise da mineração em Diamantina no período I870- I890 e os impactos que ela gerou sobre os negócios dos grandes mineradores e negociantes de diamante. A ênfase recai sobre a trajetória regional da indústria de lapidação, que representou tentativa de agregar valor às gemas extraídas nas lavras do Alto Jequitinhonha. Também são analisados os investimentos que os homens de fortuna fizeram em firmas comerciais e industriais (principalmente fábricas de tecidos) e os projetos de desenvolvimento regional elaborados por empresários diamantinenses neste período. O trabalho utiliza fontes locais diversas como inventários, processos de falências, contratos, jornais, discursos e panfletos políticos.
\end{abstract}

\section{Palavras-Chave}

Diamantina, crise da mineração, indústria de lapidação, empresários, desenvolvimento regional

\begin{abstract}
This paper examines the mining crisis in Diamantina between 1870 and 1890 and the consequences it produced on the great miners and diamond dealer's business. It enphazises the regional trajectory of the lapidary industry, that represented an attempt to aggregate value to the gemstones mined in the UpperJequitinhonha. The paper also analyses the investments carried out by the businessmen in commercial and industrial partnerships (especially fabric factories), as well as the regional development projects fostered by Diamantina's entrepreneurs in the period. This paper utilizes several local sources like inventories, liquidations processes, contracts, newspapers, political speeches and political pamphlets.
\end{abstract}

\section{KEYWORDS}

Diamantina, mining crises, lapidary industry, entrepreneurs, regional development

\author{
JEL CLASSIFICATION
}

N96; RII

\footnotetext{
* Professor do Curso de História das Faculdades Pedro Leopoldo (FPL-MG). Endereço para contato: Rua Rosalina Laranjeira, 68 - Bairro São José - Pedro Leopoldo, MG - CEP: 33.600-000. E-mail: lobatohistoria@hotmail.com.

(Recebido em janeiro de 2007. Aceito para publicação em maio de 2007).
} 
A extração de diamantes nas lavras do Alto Jequitinhonha apresentou, no século 19, fases bastante distintas que variaram da euforia ao desalento. Se tomamos os volumes de produção e os preços do diamante, as mudanças na legislação minerária e os padrões de organização das lavras, podemos propor a seguinte periodização para a atividade no Oitocentos: a) 1808 a 1832 - Primeira crise do diamante; b) 1832 a 1870 - Boom da atividade garimpeira; c) 1870 a 1897 - Segunda crise do diamante e; d) 1897 a 1930 - Reanimação da atividade mineradora.

O período 1808-1832 corresponde à crise terminal da Real Extração, no qual houve considerável queda nos volumes das partidas oficiais de diamante. Entre 1832 e 1870, ocorreu enorme frenesi na mineração no Alto Jequitinhonha, graças ao desimpedimento das lavras e aos novos descobertos de São João da Chapada e do Caeté-Mirim. Nesse período, segundo Joaquim Felício dos Santos, os garimpeiros extraíram em poucos anos mais diamantes do que a Real Extração havia conseguido no espaço de setenta anos (SANTOS, 1978, p. 377-406). A partir do ano de 1870, a euforia dos grandes mineradores e das turmas de garimpeiros cedeu lugar ao pessimismo. Sobreveio uma crise dramática que se estendeu até os anos 1890. A descoberta dos diamantes da África do Sul provocou alteração profunda no mercado mundial de gemas. Verificou-se variação muito negativa nos preços do diamante, de modo que a economia da região de Diamantina foi afetada significativamente, como mostraremos adiante. A reanimação da atividade mineradora tornou-se patente no final dos anos 1890, na esteira da instalação de companhias nacionais e estrangeiras no Rio Jequitinhonha. Houve aumento do volume de diamantes extraídos, expressiva recuperação dos preços (depois de 1905) e os investimentos realizados pelas companhias mineradoras desanuviaram o ambiente regional.

Neste trabalho, concentramos nossa atenção sobre o período compreendido entre as décadas de 1870 e 1890, caracterizado pela queda dos preços internacionais do diamante após as descobertas das minas do Cabo, na África do Sul. O primeiro objetivo é examinar a natureza e a amplitude da crise que atingiu a economia da região de Diamantina. A ênfase recai sobre os impactos desta crise nos grandes serviços de lavra e nas alteraçóes que ela provocou nos negócios dos maiores mineradores. $\mathrm{O}$ segundo objetivo do trabalho é discutir a trajetória regional da indústria de lapidação de diamantes, que representou a única tentativa dos mineradores e negociantes de pedras preciosas para agregar valor ao produto das lavras do Alto Jequitinhonha. $\mathrm{O}$ terceiro objetivo é apresentar as linhas gerais de dois projetos de desenvolvimento regional formulados pelos irmãos Antônio e Joaquim Felício dos Santos e por Pedro da Mata Machado, os quais alimentaram intenso debate nas páginas dos jornais locais e compartilharam a idéia de superar a centralidade que o diamante secularmente detinha na economia da antiga Demarcação. 
Para levar a cabo as tarefas propostas, utilizamos diversas fontes encontradas em acervos documentais na cidade de Diamantina, com destaque para os registros da Biblioteca Antônio Torres (BAT), do IPHAN-MG. As fontes incluem documentação cartorial - escrituras de compra e venda, contratos de serviços, contratos de criação de empresas, inventários, processos de falências e de concordatas etc. -, periódicos da imprensa de época, discursos e panfletos de líderes políticos diamantinenses e textos memorialísticos.

\section{A CRISE DA MINERAÇÃO DE DIAMANTES ENTRE AS DÉCADAS DE 1870 E 1890}

Na antiga Demarcação Diamantina, entre as décadas de 1870 e 1890, uma combinação de fatores negativos gerou forte incerteza sobre o futuro dos negócios e causou uma onda de falências de mineradores e negociantes.

Impotente, a região acompanhou a elevada depreciação dos preços do diamante. A partir de 1867, imensos depósitos de diamantes foram descobertos na África do Sul, na região dos rios Orange e Vaal. Em 1870, encontraram-se minas em Kimberley, Jagersfontein e Dutoitspan. O produto dessas lavras subterrâneas abarrotou o mercado mundial, forçando a queda dos preços e o deslocamento da produção brasileira para uma posição inframarginal. ${ }^{1}$ Entre 1870 e 1876, o preço da oitava de diamante de primeira despencou: caiu de 1:200\$000 (54,39 libras esterlinas) em 1870, para $200 \$ 000$ (7,76 libras esterlinas) em 1874; e, dois anos depois, reduziu-se a 170\$000, equivalente a 6,71 libras esterlinas (Acervo José Teixeira Neves. Livro 1, caixa 3, fls. XXIV e XXV. BAT). Uma queda espetacular num curto espaço de tempo. Passado o primeiro impacto, o preço dos diamantes melhorou um pouco, a partir da década de 1880. No entanto, permaneceu bem abaixo do nível que possuía em 1870. Evidência disto é fornecida pelo processo de falência do negociante Jacinto Leite de Faria, ocorrido em 1883. Na avaliação dos bens do negociante, consta uma partida de diamantes com quatorze quilates, avaliada em 450\$000 (20,87 libras). Um cálculo simples mostra que, no citado ano, a oitava de diamante estava cotada na casa de $576 \$ 450$ (26,74 libras esterlinas), praticamente metade do preço alcançado em 1870 (Jacinto Leite de Faria, processo de falência, Cartório do lo Ofício, 1883, maço 142, p. 529-30. BAT). O efeito de tal movimento de preços sobre a renda dos mineradores foi, evidentemente, muito negativo.

1 Os valores monetários relevantes para efeitos de comparação intertemporal citados neste trabalho serão convertidos em libras esterlinas, pela taxa de câmbio libra esterlina/mil-réis. Com base em IBGE (193940) e ABREU (1990). 
Em 1873, conforme José Teixeira Neves ${ }^{2}$, muitos faiscadores trocaram a mineração do diamante pela extração do ouro. E alguns diamantários foram atingidos pelo desespero, de que dá mostras o relato seguinte, referente ao ano de 1874:

\section{Um honrado negociante de diamantes do Serro investira o seu capital no negócio e seguiu para a Europa a fim de vender sua mercadoria. $O$ preço encontrado nas praças européias representava para ele um prejui- zo de $80 \%$. Regressando ao Brasil, atirou-se no mar nas proximidades de Cabo Frio. Além desse, deram-se outros suicidios pelo mesmo motivo (Acervo José Teixeira Neves. Livro 1, caixa 3, f. XXIII. BAT).}

A falência de muitos negociantes de Diamantina trouxe ainda mais turbulência para o cenário regional. Um deles foi Paulo Dias de Oliveira, em cujo processo de falência, datado de 1875 , pode-se ler:

O valor dado aos bens descritos no inventário, tendo-se em vista a crise monetária por que está passando este município, não produz talvez 20:000\$000. É sabido que poucos prédios existem nesta cidade que vendidos em praça produzem 4:000\$000, ressaltando que uma das casas hipotecadas foi avaliada em 5:500\$000. Além disso, foi igualmente avaliada por $600 \$ 000$ uma casa sita na povoação do Guinda [área mineradora], lugar que está hoje em completo abandono (...) $\mathrm{Na}$ proporção destes valores excessivos estão os mais bens descritos, e ainda mesmo os escravos, cujos preços têm baixado ultimamente por falta de compradores (Processo de falência de Paulo Dias de Oliveira, ano 1875, Cartório do $3^{\circ}$ Ofício, maço 286, p. 3-11. BAT).

A falência de Paulo Dias de Oliveira foi precipitada pela queda de preço dos ativos que possuía (imóveis, escravos, diamantes) e da capacidade de pagamento de muitos de seus fregueses. Situação similar enfrentou o já referido Jacinto Leite de Faria, negociante de fazendas e armarinhos em 1883. Sua casa comercial em Diamantina possuía vasta clientela, incluindo pessoas das famílias mais importantes da cidade. Amargando dificuldades para receber os débitos de muitos fregueses, o comerciante começou a não quitar compromissos com seus credores, razão pela qual solicitou ao Juiz Municipal declarar a falência de sua loja. Numa peça do processo, o Juiz descreveu como segue os percalços que prejudicaram Jacinto Faria:

2 José Teixeira Neves, arquivista e bibliófilo diamantinense, foi funcionário da Biblioteca Nacional em meados do século 20. Durante dezenas de anos, colheu milhares de informações sobre a história de Diamantina nos acervos do Rio de Janeiro e de Belo Horizonte, reunindo as transcrições, por temas, em dezenas de cadernos. Após sua morte, as caixas contendo esses cadernos foram doadas pela família à BAT. 
(...) tendo-se porém nos últimos anos paralisado o comércio nesta cidade, sobrevindo ao suplicante novos prejuizos como seja muitos de seus devedores não terem podido solver os seus débitos, a morte de uma escrava, um furto que the fez um seu empregado, a venda de uma partida de brilhantes por muito menos do seu valor, agravou-se a sua situação de maneira a não poder cumprir algumas obrigações já vencidas (Processo da falência de Jacinto Leite de Faria, 1883, Cartório do $1^{\circ}$ Ofício, maço 142. BAT).

As agruras vividas pelo capitão Jacinto Leite de Faria revelam como perduraram durante muitos anos as dificuldades que a economia regional enfrentou, em decorrência da violenta crise de preços internacionais do diamante iniciada em 1870. O desânimo que se abateu sobre Diamantina ficou estampado nas páginas dos jornais locais:

A grande baixa no preço dos diamantes que começou no ano de 1870, e sustenta-se até hoje, tem trazido como conseqüência um tal desánimo para os habitantes das regiões diamantinas, que a maior parte deles pensa seriamente na necessidade da emigração para lugares onde o trabalho encontra melhor recompensa, e onde a atividade comercial possa desenvolver-se mais proficuamente. As matas do sul da Provincia, $e$ do Rio de Janeiro, (...) são o ponto para o qual convergem as vistas, e muitos de nossos patricios, pais de familia, ou moços principiantes já para lá se têm dirigido... (Monitor do Norte, ano 2, n. 9, p. 1, 13 de fevereiro de 1876. Acervo Soter Couto, gaveta 2, maço 13. FAFIDIA, Diamantina).

A matéria do Monitor do Norte reconhece que o estado de crise da mineração não apenas afetava o rendimento dos garimpeiros, mas tirava-lhes até mesmo as oportunidades de trabalho, de maneira que a migração de trabalhadores ganhou intensidade na região. Outro indicador deste fato aparece no exame das transações de compra e venda de escravos. Ao contrário do que ocorria na década de 1860, passaram a predominar os registros de vendas de cativos para fora da região, na direção do sul de Minas e Rio de Janeiro, para localidades como o Rio de Janeiro, Leopoldina, São Paulo de Muriaé, Ubá e Oliveira. A Tabela 1, construída a partir de pequena amostra dos registros de vendas de escravos na Diamantina de 1872 a 1881, permite visualizar este processo: 
TABELA I - REGISTROS DE VENDAS DE ESCRAVOS - DIAMANTINA - 1872 A 1881

\begin{tabular}{lccc}
\hline Tipos de transação & n. & n. escravos & \% total de escravos \\
\hline Vendas para fora da região & 31 & 43 & 66,1 \\
Vendas dentro da região & 16 & 22 & 33,9 \\
Total & 47 & 65 & 100 \\
\hline
\end{tabular}

Fonte: Livros de Notas 3, 5, 6, 7, 8, 9 e 10, maço 162; 35 e 36, maço 161. BAT.

Considerados somente os cativos vendidos para fora da região, há indicações da profissão para 23 deles. Dentre estes, oito eram mineiros $(34,8 \%)$, sete eram serventes $(30,4 \%)$, três roceiros $(13,0 \%)$, três cozinheiros $(13,0 \%)$, um marceneiro $(4,4 \%)$ e uma costureira $(4,4 \%)$. Conforme Roberto Borges Martins, em 1855 a população escrava da região Jequitinhonha-Mucuri-Doce era de 35.352 cativos, representando $11 \%$ do total provincial. Em 1873, o contingente de cativos da região era de 34.838 escravos, equivalendo a $9 \%$ do total provincial. No período $1855-1873$, este pesquisador calculou que o município de Diamantina teria perdido 1.913 escravos (MARTINS, 2002, p. 122-123). Estes números sugerem que o setor da mineração enfrentava graves dificuldades na década de 1870 .

Outra faceta da crise da mineração está associada ao aumento dos conflitos pela posse das lavras, bem como às incertezas decorrentes das ambigüidades e modificações da legislação brasileira, na transição da Monarquia para a República. O regime de livre exploração possibilitou o avanço contínuo do processo de concentração dos terrenos diamantinos nas mãos de poucos proprietários, que freqüentemente especulavam com os lotes de terras minerais. Este processo alimentou disputas às vezes dramáticas pelas áreas de extração mineral. Os conflitos entre garimpeiros e grandes mineradores intensificaram-se, ocorrendo em torno dos novos descobertos - no Arraial do Curralinho, no Rio das Pedras, nas lavras do Barro Duro e Barro Mole, no Pau de Fruta. Em 1873, os terrenos diamantinos do Pau de Fruta foram invadidos por cerca de 5 a 6 mil faiscadores, que fizeram surgir, em uma semana, "uma espécie de república bem organizada". Duas companhias de soldados da Polícia, sob o comando do Capitão Felipe Coelho dos Santos, marcharam para o local, impuseram a ordem e gradativamente dispersaram os faiscadores (Acervo José Teixeira Neves, Livro 1, caixa 3, folha XXXVIII. BAT). Outros exemplos podem ser citados, mostrando que os conflitos pelo controle de áreas de mineração atravessaram toda a segunda metade do século 19, arrastando-se pelo século 20 adentro (MARTINS, 1997). 
No período em tela, mesmo que os pequenos mineradores conseguissem garimpar sossegados, ainda assim acabariam vitimados pela ação dos chamados diamantários (os negociantes locais de diamantes) que, na conjuntura da crise, sistematicamente "salgaram" as partidas de gemas que lhes eram oferecidas. Os grandes compradores de diamantes, como Josefino Vieira Machado (Barão de Guaicuí), Antônio Eulálio de Souza e o Comendador Serafim Moreira da Silva, aviltavam de maneira combinada os preços das pedras, prejudicando os garimpeiros. Tal expediente era possível porque, até o ano de 1912, "a compra de diamantes, em Diamantina, constituía quase um privilégio da conbecida casa dos Srs. Luiz de Rezende \& Cia. do Rio de Janeiro, representando capitais ingleses, franceses e holandeses" (O Momento, 15 de janeiro de 1922, p. 3, maço 91, gaveta 6. BAT).

A legislação relativa à mineração também contribuiu para tornar mais confuso o cenário no setor, entre as décadas de 1870 e 1890. A Constituição de 1824 preconizava o regime dominial, pelo qual os minérios pertenciam ao Estado e o controle da mineração cabia às Províncias. Em Minas Gerais, por volta de 1860, foi criada a Repartição dos Terrenos Diamantinos, subordinada à Secretaria de Governo, Quarta Seção, durante o período 1866-1889. Esta repartição, sediada em Diamantina, tinha as seguintes funções: demarcar e registrar as áreas minerais, promover os leilões de terrenos diamantinos e registrar os exploradores. O órgão tornou-se, na prática, um instrumento dos interesses dos grandes mineradores de Diamantina. Todavia, avolumaram-se as críticas à legislação minerária do Império e, com a Proclamação da República, houve alteração drástica neste campo. A Constituição de 1891 estabeleceu o direito fundiário para a mineração, que afirmava que as minas pertenciam aos proprietários dos solos. Imediatamente, os mineradores fizeram queixas contra as imposições dos donos das terras. As porcentagens cobradas pelos proprietários sobre o resultado bruto dos serviços de lavra descontentaram os mineradores, além de acirrar os conflitos pelo controle dos terrenos minerais. Para os diamantinenses, havia ainda o problema de que o governo estadual cogitava transferir a Repartição dos Terrenos Diamantinos para a capital, bem como aumentar os impostos sobre as áreas de lavra. Os grandes mineradores e os diamantários da cidade enxergaram estas pretensões do governo como tentativas de enfraquecer seu controle sobre o diamante, de modo que se opuseram tenazmente aos desígnios do Estado. A disputa atingiu o clímax em janeiro de 1904, quando um ato de insurreição paralisou Diamantina. Conforme o jornal O Itambé, ocorreu uma "sublevação do povo. Diamantina em massa nas ruas. Comércio fechado. Tomada do arquivo dos Terrenos Diamantinos" (O Itambé, ano 3, n. 103, 31 de janeiro de 1904, p. 1, gaveta 6, maço 92. BAT). O governo de Minas Gerais recuou, as elites diamantinenses cantaram vitória.

Do que foi dito anteriormente, depreende-se que a crise da mineração no Nordeste de Minas Gerais, ocorrida entre as décadas de 1870 e 1890, teve a ver com a queda 
de preços internacionais das gemas, com a intensificação dos conflitos entre mineradores, garimpeiros e donos de terras, com a emigração de trabalhadores, com mudanças na legislação brasileira e com as incertezas sobre a continuidade do controle político diamantinense da Repartição dos Terrenos Diamantinos. Portanto, era uma crise simultaneamente econômica e política. Para superá-la, a cidade teria que tomar iniciativas no campo da economia e da política.

\section{AS RESPOSTAS DOS GRANDES MINERADORES À CRISE DAS DÉCADAS DE 1870-1890}

A conjuntura negativa das décadas de 1870-1890 não propiciou alterações técnicas expressivas nos procedimentos de lavra nas unidades mineradoras do Alto Jequitinhonha. As grandes lavras continuaram empregando trabalho manual, técnicas tradicionais e instrumentos que podiam ser produzidos em pequenas oficinas de ferreiros e carpinteiros. O inventário de Rodrigo de Souza Reis descreve a Lavra da Perpétua em 1872. O terreno mineral media 20 mil braças, possuía aguada e terras de pasto e cultura, tudo avaliado em 3 contos de réis. As instalações (casa, rancharia, moinhos) valiam 4 contos e 563 mil réis (182,52 libras esterlinas). Os animais (bestas e gado) da lavra estavam avaliados em 285 mil réis. Os instrumentos de mineração, inclusive duas rodas de minerar, somavam $852 \$ 400$ (34,10 libras). Em termos de capital fixo, desconsiderados os escravos, a Lavra da Perpétua representava 8:700\$400, equivalentes a 348 libras esterlinas (Inventário de Rodrigo de Souza Reis, 1872, Cartório do $2^{\circ}$ Ofício, maço 286, fls. 21-29. BAT). Vinte e cinco anos depois, a Lavra dos Caldeirões, de propriedade do Comendador Serafim Moreira da Silva, era muito semelhante à Lavra da Perpétua. Na Lavra dos Caldeirões, cujo valor total era de $679 \$ 900$ (88,07 libras esterlinas) não havia atividade agropecuária, mas o serviço contava com uma tenda de ferreiro (com dois foles), avaliada em $60 \$ 000$. Havia uma casa coberta de telhas que abrigava os trabalhadores e a cozinha, avaliada em 150\$000; os instrumentos de mineração, incluindo uma roda com todos os seus pertences (200\$000), somavam $466 \$ 900$ (Inventário do Comendador Serafim Moreira da Silva, 1897, Cartório do $2^{\circ}$ Ofício, maço 231. BAT).

Em decorrência da queda dos preços do diamante, os grandes mineradores procuraram preservar suas margens de rentabilidade reduzindo as despesas com os trabalhadores. Para tanto, ampliaram o emprego de uns poucos equipamentos rudimentares poupadores de mão-de-obra, caso das rodas de minerar e das jangadas, equipamentos artesanalmente fabricados em oficinas da região que facilitavam a drenagem das "catas", diminuindo o número de homens/hora necessário para secar as áreas a serem mineradas no leito dos córregos. Por outro lado, insistiram no sistema de praças e 
meias-praças, que mantinha baixa a participação dos trabalhadores no resultado das apurações dos serviços. Nas lavras comandadas pelo Comendador Serafim Moreira da Silva podemos ver a organização do trabalho que então predominava. Em 2 de março de 1893, Antônio Nonato de Campos celebrou contrato com o Comendador, nos seguintes termos:

Eu abaixo assinado, arrendatário de um lote de terreno diamantino, sito no Rio Pinbeiros, (...) cujo lote vendi a meu pai Raymundo Nonato de Campos, e ainda não lhe fiz transferência, mas tendo o referido meu pai contratado com o Senhor Comendador Serafim Moreira da Silva, para este senhor explorar o mesmo lote com a condição de dar a meu pai em seu mapa três serviços diários, depois de extraídas as despesas de trabalho e alimentação pessoal, e dos lucros verificados dividir-se pelo número de serviços existentes, só cabendo a meu pai a parte relativa aos três serviços diários, e se por acaso o serviço der prejuizo não ficará $o$ dito meu pai sujeito a despesa alguma, correndo tudo exclusivamente por conta do senhor Comendador... (Livro de Notas n. 22, Cartório do $1^{\mathrm{o}}$ Ofício, maço 43 , p. v-4. BAT).

Este contrato permite compreender o mecanismo que realizou a subordinação econômica dos garimpeiros aos grandes mineradores e negociantes de diamantes, processo acelerado pela crise das décadas de 1870-1890. Os grandes mineradores arrendavam os terrenos, celebrando contratos com os proprietários de terras; em seguida, acertavam combinações com turmas de garimpeiros, sem recursos por causa da crise dos preços das gemas, e bancavam os custos operacionais dos trabalhadores. Os lucros provenientes da apuração das lavras eram divididos de acordo com o número dos "serviços diários", isto é, o número de praças que atuavam na lavra. Naturalmente, o grande minerador ficava com a parte do leão nos resultados das lavras.

Quando os preços dos diamantes atingiram o nível mais baixo, no ano de 1874, as elites de Diamantina, encabeçadas pelo Bispo Dom João Antônio dos Santos, enviaram uma representação à Câmara Municipal (7 de maio de 1874), na qual ponderavam a necessidade de solicitar medidas ao governo imperial de amparo aos mineradores e sugeriram "a idéia de contrair esta Câmara um empréstimo com o fim de criar neste município uma fábrica de tecidos de algodão" (apud. SOUZA, 1993, p.128-129). Diante da gravidade da crise da mineração, as elites diamantinenses consideraram a saída industrial, recorrendo ao Poder Público. Proposta que lembra o Estado-empresário, eco da Real Extração. De concreto mesmo, a Câmara deliberou, em 9 de maio de 1874, o seguinte: 
A Comissão Permanente a qual foi presente uma representação assinada por vários cidadãos pedindo que esta Câmara tome providência a fim de atenuar o estado de miséria a que tem chegado a população do município, em virtude da grande baixa do diamante, é de parecer que esta Câmara com urgência represente à Assembléia Geral Legislativa, chamando sua atenção sobre os seguintes pontos: em que se pede na supracitada representação que sejam relevadas as multas e pagamentos de arrendamentos de lavras dos arrendatários que não os pagaram desde o ano de 1870; em que se pede a suspensão da cobrança dos direitos de arrendamento de lavras até 1876 e, finalmente, que se pede que se franqueie a exploração dos terrenos devolutos gratuitamente. A representação desta Câmara deve ser dirigida aos Deputados deste Distrito... (Folha avulsa, assinada por C. Rabello, Vieira Machado e Pedro Brandão. Livro da Comissão de Alistamento Eleitoral B, diversos anos, 1857-1902. Arquivo da Câmara Municipal de Diamantina).

Esta representação da Câmara de Diamantina não deixa dúvidas sobre os interesses mais imediatos dos grandes mineradores: para manter preservados seus ganhos, na conjuntura da crise que a região experimentava, exigiam a supressão das multas e dos impostos atrasados, e pleiteavam nada menos do que o franqueamento dos terrenos minerais. A eliminação completa, por tempo razoável, de todos os impostos e controles burocráticos que incidiam sobre a mineração do diamante. Estas reivindicações não foram atendidas pelo governo.

Os maiores mineradores, comparativamente menos afetados pela crise do que os pequenos mineradores, garimpeiros e faiscadores, trataram de concentrar em suas mãos os terrenos diamantinos. Aproveitaram a ocasião para comprar muito barato diversos lotes minerais. Os numerosos registros destas transações encontram-se espalhados pelos Livros de Notas dos Cartórios de Diamantina. Aqui oferecemos somente dois exemplos. Em 26 de fevereiro de 1874, João da Mata Machado comprou de Cassiano Feliz Ferreira uma chácara e o direito que este tinha em dois lotes de terrenos diamantinos no Córrego Baú, tudo pela quantia de 500 mil réis (19,39 libras). Um dos lotes negociados media 6 mil braças quadradas e o outro, 8 mil (Livro de Notas n. 6 , Cartório do $3^{\circ}$ Ofício, maço 162, p. 6-8. BAT). Em 31 de outubro do mesmo ano, Denis Moreira dos Santos comprou um lance de serviços de mineração no Ribeirão do Inferno, pertencente a Venâncio Ribeiro Mourão, pela quantia de 2 contos de réis (77,58 libras). A lavra, de 6 mil braças quadradas, foi adquirida com "vinte praças vivas", o que significa um preço baixo para uma jazida potencialmente rica (Livro de Notas n. 7, Cartório do $3^{\circ}$ Ofício, maço 162, p. 50v-52. BAT). 
A corrida pela aquisição de lotes diamantinos foi compensada no final da década de 1890, época na qual começaram a ser formadas as companhias nacionais e estrangeiras de mineração do diamante. Estas companhias precisavam de áreas para lavrar e estavam dispostas a pagar bem por elas. Os grandes mineradores de Diamantina souberam aproveitar a oportunidade: especularam com o valor destes terrenos, engordando suas fortunas. Mais uma vez, apresentamos apenas dois exemplos destas transações. Em 20 de novembro de 1897, o tenente-coronel Antônio Eulálio de Souza constituiu seu bastante procurador o Dr. Francisco José de Almeida Brant, residente em Ouro Preto, com poderes especiais para transferir para a Companhia Boa Vista um lote de terrenos diamantinos, de 44 mil metros quadrados, no lugar denominado Boa Vista (Livro de Notas n. 46, Cartório do $2^{\circ}$ Ofício, maço 16l, p. 38v-39. BAT). Já o coronel Justiniano Fernandes de Azevedo, em 27 de novembro de 1897, constituiu seu procurador a Charles Spitz, para vender ou ceder concessões que possuía nas cabeceiras do Jequitinhonha, em sociedade com outros mineradores. Os lotes seriam vendidos pela quantia total de 500 contos de réis (64.767 libras esterlinas), o pagamento podendo ser realizado em ações das companhias interessadas (Ibidem, p. 46-47v).

Ao mesmo tempo em que buscaram a subordinação econômica dos garimpeiros, a concentração dos lotes diamantinos e os ganhos especulativos daí derivados, os grandes mineradores do Alto Jequitinhonha despertaram para a conveniência de conhecer todos os meandros da "indústria do diamante". Organizaram representações que partiram para o Rio de Janeiro, Lisboa, Londres e Amsterdã. Os representantes dos mineradores de Diamantina visitaram casas compradoras de diamantes, lapidações, joalherias e empresas mineradoras. Voltaram convencidos de que o diamante deveria ser industrializado. Desta disposição surgiu o impulso para a instalação da indústria da lapidação no antigo Tijuco.

Em 1873, o jornal O Jequitinhonha saudava o nascimento do setor de lapidação em Diamantina: "Vimos vários brilhantes lapidados na fábrica diamantinense do Comendador Serafim Moreira da Silva pelo Sr. Josefino Pereira da Silva. O trabalho perfeito. Enfim! Está criada a indístria da lapidação em Diamantina pela iniciativa individual" (O Jequitinhonha, 2 de setembro de 1873. BAT).

As principais lapidações do município foram instaladas entre os anos de 1873 e 1875, principalmente na cidade de Diamantina e no distrito de Gouveia. Os pioneiros do setor foram: o comendador Serafim Moreira da Silva, fundador da "Fábrica da Palha" (1873); o Barão de São Roberto, fundador da "Fábrica Vitória Augusta" (1874) e o conselheiro João da Mata Machado, fundador da "Fábrica da Formação" (1875). Todos eles mineradores e negociantes de diamantes. Os lapidários responsáveis por estes empreendimentos eram oficiais de origem portuguesa, que aprenderam 
a arte de lapidar no Rio de Janeiro. No ano de 1878, os irmãos Felício dos Santos fundaram a lapidação do Biribiri, com 18 rodas, dentro das instalações da fábrica de tecidos da firma Santos \& Cia.

Segundo José Teixeira Neves, no ano de 1887 as principais lapidações de Diamantina eram: a Fábrica de Biribiri, com 42 rodas de lapidar; a Fábrica Vitória Augusta, instalada em Gouveia, com 18 rodas; a Fábrica da Formação e a da Palha, ambas com 12 rodas e localizadas nos subúrbios da cidade. Todas essas lapidações empregavam força hidráulica para mover seus maquinismos e mão-de-obra recrutada no seio da juventude da região. O capital de giro era fornecido pela fortuna de seus proprietários, há muito envolvidos no comércio regional de pedras. A Fábrica Vitória Augusta foi fechada na ocasião da morte de seu fundador, o Barão de São Roberto, em 1895. A Fábrica da Palha também teve suas atividades encerradas com a morte do comendador Serafim Moreira da Silva, no ano de 1897. A Fábrica do Biribiri, ligada principalmente a Antônio Felício dos Santos, funcionou regularmente até meados da primeira década do século 20, quando a firma Santos \& Cia. começou a enfrentar forte crise financeira. Em 1911, a referida lapidação foi fechada, no momento da passagem do controle da Fábrica de Tecidos de Biribiri para as mãos do Banco Hipotecário do Brasil.

Em 1887, a produção anual de diamantes lapidados no município teria sido de $3.48 \mathrm{lg}$, aproximadamente 17.400 quilates. Já no ano de 1890, havia no município de Diamantina 146 pessoas ocupadas nas fábricas de lapidação, cuja produção anual girou em torno de 5.520 quilates. A produção do ano de 1890 representou menos de um terço da produção de diamantes lapidados do ano de 1887.

Entre 1875 e 1882, havia muitas lapidações com menos de seis rodas de lapidar, instaladas em diversos pontos do município - Curralinho, Mendanha, Sopa, Palmital, Rio Manso, Caeté-Mirim e Datas. Seus proprietários eram negociantes de pedras sem maiores recursos, que não conseguiam comprar gemas brutas em quantidade. Para atrair fregueses, os donos dessas pequenas lapidações e os lapidários dispararam uma "guerra de preços", reduzindo dia após dia o valor cobrado pelos serviços de corte e polimento dos diamantes, afetando inclusive os preços dos serviços das maiores lapidações. Os jornais anunciaram em suas páginas os lances dessa guerra: "A contar-se de primeiro de junho próximo em diante, a lapidação de diamantes de terceiros na Fábrica da Formação, será por combinação dos sócios, para os diamantes de quilate para cima na razão de 15\$000[0,55 libras] por quilate e para os de 20 quilates para cima o que se convencionar" (Monitor do Norte, ano 1, n. 51, 28 de novembro de 1875. Gaveta 2, maço 12. Acervo Soter Couto. Faculdade de Filosofia e Letras de Diamantina, FAFIDIA). "O abaixo assinado declara que na sua fábrica d’ora $\mathrm{em}$ diante, se lapida diamantes de um quilate para cima, a doze mil réis $-12 \$ 000[0,47$ li- 
bras]. Igualmente, cliva (corta) diamantes em qualquer parte que convenha a seu dono, a quatro mil réis o quilate, 4\$000. Diamantina, 14 de fevereiro de 1876. Serafim Moreira da Silva" (Monitor do Norte, ano 2, n. 9, 13 de fevereiro de 1876. Gaveta 2, maço 13. Acervo Soter Couto. FAFIDIA). "Fábrica de lapidação. Lapida-se diamantes de quilate para cima, na fábrica de João da Mata Machado, a $\$ \$ 000[0,32$ libras] por quilate e de menos quilates até doze grãos a $10 \$ 000$ por quilate. Garante-se perfeita lapidação e brevidade" (Monitor do Norte, ano 2, n. 9, 13 de fevereiro de 1876. Gaveta 2, maço 13. Acervo Soter Couto. FAFIDIA).

Josefino Pereira da Silva, tendo separado a sociedade particular que tinha com o Sr. Luiz Paulino de Oliveira Miranda, participa aos seus numerosos fregueses que continua a trabalhar na mesma fábrica da Palha; $e$ atendendo a escassez de diamantes e dificuldades de venda dos brilhantes, resolveu-se a lapidar desta data em diante a 7\$000[0,29 libras] por quilate sendo de 4 quilates para cima, e que em vista da redução de preço na lapidação e grandes despesas da fábrica e oficiais, não pode mais trabalhar fiado. Aproveitando esta ocasião pede a todos os fregueses que ficaram devendo lapidação virem quanto antes saldar suas contas. (Diamantina, ano 3, n. 14, 8 de julho de 1877. BAT).

As numerosas lapidações de tamanho reduzido, com menos de seis rodas de lapidar, não possuíam recursos para investir em equipamento e na qualificação profissional dos lapidários. Operaram de forma rotineira e irregular, trocando de proprietários diversas vezes, em transações que só faziam depreciar o capital nelas empregado. A "Fábrica de Cafundós", situada no distrito de Curralinho, ilustra esta faceta da trajetória das lapidações da região. Adquirida um ou dois anos antes das mãos de um minerador da localidade pelo casal Joaquim José Ferreira Rabelo e Dona Amélia Eulália Vieira Rabelo, a lapidação possuía seis rodas. No dia 4 de novembro de 1878, os novos donos lavraram escritura de venda de "duas forças de roda de lapidação e partes competentes" para João Antônio, pela quantia de 500\$000 - 21,80 libras (Livro de Notas n. 36, Cartório do $2^{\circ}$ Ofício, maço 161, p. 51-52. BAT). Esta pequena lapidação, a partir de então, ficava dividida entre dois proprietários, cada um deles com número ínfimo de rodas de lapidar. Que perspectivas de sucesso tal arranjo poderia produzir? As pequenas lapidações, lidando com o diamante da região que é de lapidação mais difícil, operando com técnicas e equipamentos defasados em relação aos empreendimentos congêneres do Rio de Janeiro e da Europa, lutando contra o costume da venda fiada e enfrentando a baixa saída dos brilhantes na praça do Rio, entraram numa espiral de endividamento, que rapidamente levava os empreendimentos à falência. 
Mesmo as maiores lapidações, ligadas a homens de negócio de grande fortuna, tiveram dificuldades para expandir sua produção e aperfeiçoar a qualidade dos serviços de corte e polimento, tanto em função da queda dos preços do diamante como da baixa aceitação pelo mercado carioca das pedras lapidadas em Diamantina. Na medida em que os preços dos serviços de lapidação mantiveram-se comprimidos, inclusive por causa da concorrência das pequenas "fábricas de lapidar", faltaram recursos para a modernização do setor. Isso porque, para homens como Serafim Moreira da Silva, Antônio Eulálio de Souza, Antônio Cassimiro de Almeida, José Alexandre de Souza, Licínio Balsamão e outros diamantinenses, a expansão dos negócios deveria ocorrer exclusivamente por meio do reinvestimento de lucros, sem recorrer à emissão de debêntures ou aos empréstimos bancários. Este foi o comportamento de diversos pioneiros da indústria têxtil mineira verificado por Maria Teresa Ribeiro de Oliveira. (OLIVEIRA, 2002, p. 244). Não surpreende, portanto, que a Fábrica da Formação, do conselheiro Mata Machado, mantivesse as mesmas 12 rodas no período 1875 1915; e que a Fábrica da Palha, iniciada em 1873 com 12 rodas, alcançasse 18 rodas no começo dos anos 1880, mas em 1887 voltasse a ter 12 rodas.

A Tabela 2 traz informações sobre o capital imobilizado em algumas lapidações de Diamantina:

TABELA 2 - CAPITAIS EMPREGADOS EM LAPIDAÇÕES DE DIAMANTINA -1878 A 1902

\begin{tabular}{llrrr}
\hline Ano* & \multicolumn{1}{c}{ Proprietário } & N. rodas & Capital & $\begin{array}{r}\text { Capital } \\
\text { (libras) }\end{array}$ \\
\hline 1878 & Joaquim José Ferreira Rabelo & 06 & $1: 500 \$ 000$ & 65,39 \\
1895 & Quintiliano A. Ferreira (B. de S. Roberto) & 18 & $6: 000 \$ 000$ & 603,62 \\
1895 & Luiz Augusto de Ávila & 04 & $3: 764 \$ 080$ & 378,68 \\
1896 & Souza \& Balsamão & 09 & $36: 000 \$ 000$ & $3.973,51$ \\
1902 & Antônio Cassimiro de Almeida & - & $4: 800 \$ 000$ & 401,00 \\
1902 & Antônio Eulálio de Souza & - & $10: 000 \$ 000$ & 835,42 \\
\hline
\end{tabular}

Fonte: Acervo José Teixeira Neves, Inventários e Livros de Notas. BAT.

Nota: * $\mathrm{O}$ ano assinalado refere-se à data para a qual há registro do capital do empreendimento.

As informações do quadro devem ser lidas com cautela. Em primeiro lugar porque, nos negócios do diamante, a informalidade foi (e continua sendo) a regra, de modo que os dados são lacunares e pouco precisos. Uma cortina de fumaça escondia as atividades dos mineradores e negociantes de gemas, que buscaram insistentemente fugir do controle do fisco. Em segundo lugar, os registros existentes nos Livros de Notas dos cartórios diamantinenses referem-se às firmas lapidárias, sem discriminar, 
na ampla maioria dos casos, as cifras concernentes a instalações, terrenos, máquinas e equipamentos. Por exemplo, o capital da firma de Luiz Augusto de Ávila incluía o valor de duas casas baixas de morada, cobertas de telhas e sitas no Arraial de Datas, e o valor dos terrenos, instalações e equipamentos da fábrica de lapidação, no lugar denominado Cachoeira do Dada (Escritura de Dívida e Hipoteca, Cartório do $1^{\circ}$ Ofício, Livro de Notas 19, maço 42, p. 42-44. BAT). Já no caso da firma Souza \& Balsamão, o capital mencionado inclui as quantias destinadas pelos sócios para a aquisição de diamantes, isto é, o capital de giro inicial da empresa, que ficava na casa de 24 contos de réis, como se mostrará adiante.

A organização do trabalho nas maiores lapidações da região não seguia modelo único. Na Fábrica do comendador Serafim Moreira da Silva, o mestre lapidário e os aprendizes eram diretamente contratados e pagos pelo proprietário. O contrato de Josefino Pereira da Silva com o comendador, assinado em 1873, estipulava para o lapidário as seguintes cláusulas:

a) o salário do oficial seria de seiscentos mil réis mensais, como gratificação pelas pedras que o Comendador apresentar a fim de aprender a arte de lapidação; porém, se a quantia lapidada anualmente na fábrica ultrapassar os seiscentos mil réis, ele receberia o valor de mil réis por quilate cortado e polido; b) os diamantes que o proprietário permitisse aos aprendizes lapidar nos domingos e dias santos não entrariam nos cálculos de remuneração do oficial; c) o oficial obrigava-se a ficar no trabalho da Fábrica até $1875 \mathrm{e}$; d) toda despesa de comestiveis correria por conta do proprietário (Livro de Notas n. 19, Cartório do $1^{\circ}$ Ofício, maço 42, p. 8v-10v. BAT).

Documento similar foi firmado entre o comendador e os aprendizes de sua lapidação, os jovens Olegário José de Figueiredo, Rafael Antônio Coelho e Elias Cândido da Silva (Ibidem, p. 10v-12v), pelo qual estes últimos se dispunham a trabalhar "do nascer ao pôr do sol" exclusivamente para a Fábrica do comendador, durante cinco anos, sob pena de pagar multas elevadas caso rescindissem o contrato. Os aprendizes comprometiam-se, também, a lapidar somente os diamantes do proprietário.

Era outro o modelo de funcionamento da lapidação dos franceses Richies \& Vial, situada na Palha. Suas rodas eram alugadas para os discípulos dos mestres lapidários Josefino Pereira da Silva e Luiz Paulino de Oliveira Miranda (Acervo José Teixeira Neves, caixa 7, envelope 5, f. VII. BAT). Um terceiro modelo de funcionamento de lapidação aparecia na empresa Souza \& Balsamão, que começou a operar no distrito de Datas em 1896, com nove rodas de lapidar. Esta sociedade mercantil tinha os objetivos de comprar diamantes, lapidá-los e vendê-los nas praças de Diamantina e 
do Rio de Janeiro. O capital social da firma era de 36 contos de réis $(3.973,51$ libras esterlinas) - 24 contos fornecidos por José Alexandre Souza e 12 contos por Licínio de Oliveira Balsamão. O primeiro sócio encarregava-se da compra dos diamantes, o segundo do trabalho de lapidação e ambos da venda dos brilhantes, com divisão igual de lucros e prejuízos. Cada um deles poderia fazer retiradas mensais de até 200 mil réis (Livro de Notas n. 19, Cartório do $1^{\circ}$ Ofício, maço 42, p. 86-7. BAT).

Já no ano de 1877, o jornal Monitor do Norte percebeu que o futuro das lapidações de Diamantina não seria tão promissor quanto desejara, em 1873, o editorial do periódico O Jequitinhonha. Em 4 de fevereiro de 1887, o Monitor do Norte publicou a seguinte matéria:

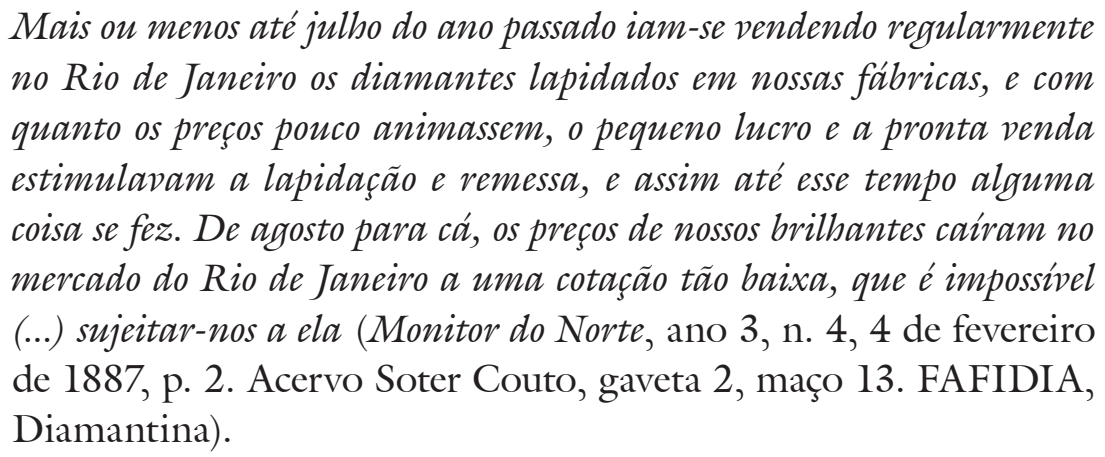

Para os redatores do Monitor do Norte, a razão do problema era dupla: de um lado, o fato de que "o Rio, na verdade, [era] um mercado relativamente pequeno, [que] não comporta grande sortimento de diamantes lapidados"; de outro lado, a queda dos preços dos brilhantes era principalmente decorrência da ação dos "especulistas da Europa, que têm interesse em fazer desaparecer as nossas fábricas". Para enfrentar o problema, os redatores sugeriram que os diamantinenses continuassem a lapidar suas gemas, mas que as retivessem pelo tempo necessário para fazer subir os preços dos brilhantes, e só então enviá-los ao Rio de Janeiro. A proposta dos homens de imprensa da cidade simplesmente não era factível, porque exigia um grau de articulação entre os atores, envolvidos na restrição voluntária da oferta de brilhantes, nunca encontrado no mundo da mineração regional (MARTINS, 1997). Na verdade, o problema pouco decorria da ambição dos europeus, mas do fato de que a indústria local não possuía condições para enfrentar a da Capital e a da Europa por causa da deficiência da aparelhagem e da menor qualificação de seus lapidários. Por isso, "no Rio, no Pátio dos Milagres, onde existe o comércio de diamantes lapidados, as pedras de lapidação defeituosa são consideradas 'pedras de lapidação diamantina"' (Voz de Diamantina, ano 3, n. 1, p. 4, 26 de março de 1938. BAT). 
A Tabela 3 traz informações sobre a variação temporal do número de lapidações no município de Diamantina, mostrando que o setor estava em vias de desaparecer a partir da década de 1890 :

\begin{tabular}{|c|c|c|c|}
\hline \multirow{2}{*}{ Ano } & \multicolumn{3}{|c|}{ Número de lapidações } \\
\hline & Com 10 ou mais rodas & Com menos de 10 rodas & Total \\
\hline 1875-1882 & 06 & 12 & 18 \\
\hline 1887-1892 & 04 & 03 & 07 \\
\hline 1896 & 04 & 01 & 05 \\
\hline 1912 & 01 & 01 & 02 \\
\hline 1916-1919 & 03 & - & 03 \\
\hline
\end{tabular}

Fonte: Acervo José Teixeira Neves. A Estrela Polar, n.46, 24 novembro de 1912. BAT

Na década de 1910, restava no município apenas uma lapidação digna de destaque: a Fábrica da Formação, adquirida em 1915 por José Neves Sobrinho, grande comerciante (proprietário da "Casa Cruzeiro do Sul") e comprador de diamantes. Assim que assumiu o comando da lapidação da Formação, José Neves Sobrinho pôs a funcionar 36 rodas de lapidar e instalou luz elétrica e telefone nas dependências do empreendimento, no ano de 1919. No serviço de lapidação de José Neves Sobrinho trabalhavam, em 1922, 36 operários, gerando produção anual de 400 quilates de pedras lapidadas, com valor estimado em 350 contos de réis, ou 48.409 libras esterlinas. ${ }^{3}$ A remuneração dos operários era pelo "sistema de empreitada" - recebiam de acordo com sua capacidade de trabalho, de $8 \$ 500$ a $60 \$ 000$ o quilate lapidado, conforme o tamanho do diamante e a qualidade do trabalho realizado (O Momento, 15 de janeiro de 1922, p. 3, gaveta 6, maço 91. BAT). Quando os negócios de José Neves Sobrinho foram enredados pela crise de 1929, a fábrica de lapidação recebeu avaliação de 100 contos de réis, ou 2.273 libras esterlinas (Concordata preventiva de José Neves Sobrinho, 1930, Cartório do $2^{\circ}$ Ofício, maço 216, p. 4. BAT).

A forte redução do número de lapidações nas primeiras décadas do século 20 pode ser explicada agregando-se, aos fatores anteriormente citados, a tendência ascendente dos preços dos diamantes a partir de 1905. Com a entrada vigorosa dos americanos

3 Cabe destacar que, conforme o Relatório do Secretário das Finanças de Minas Gerais (Belo Horizonte: Imprensa Oficial do Estado, 1929), referente ao exercício de 1928, a exportação de diamantes e pedras preciosas (em gramas), no ano de 1922, foi de 707.311. Vê-se, pois, que a quantidade de diamantes lapidados nesse mesmo ano em Diamantina, 400 quilates, é ínfima. Na verdade, isso ocorreu em todo o período aqui estudado. 
no mercado regional de pedras, logo após o término da Primeira Guerra, o preço da oitava de diamante ficou em torno de três contos de réis (cerca de incríveis 210 libras esterlinas) por alguns anos. ${ }^{4}$ Assim, para os mineradores locais não fazia sentido lapidar as gemas extraídas. O melhor era vendê-las rapidamente, brutas mesmo. Esse foi o golpe de misericórdia no setor.

Olhada em perspectiva, portanto, a indústria da lapidação em Diamantina fracassou redondamente porque não logrou alcançar os objetivos esperados no início da década de 1870. As lapidações do município, tecnicamente defasadas e a maioria delas de funcionamento bastante curto e irregular, processaram quantidades reduzidíssimas das pedras extraídas nas lavras da região, agregando pouco valor ao principal produto da economia regional.

Curiosamente, os grandes mineradores e negociantes de diamantes da região não fizeram investimentos no setor de joalheria, outra atividade que poderia agregar valor ao produto das lavras do Alto Jequitinhonha. Ramo complementar à lapidação, a joalheria foi deixada a cargo de oficiais de origem portuguesa, há muito radicados em Diamantina. Os joalheiros da cidade chegaram a alcançar fama nacional graças, principalmente, às peças de "coco e ouro", uma especialidade da região. As joalherias locais eram pequenas oficinas, com poucos equipamentos e bancadas de trabalho. Nelas, laboravam o ourives e mais um ou dois aprendizes. O mais comum era o trabalho familiar: a profissão de ourives passava de pai para filho. Uma evidência documental da reduzida dimensão das joalherias da cidade é fornecida pela escritura de venda que fez Dona Josefina Augusta Pimenta. Em 3 de junho de 1878, a esposa do finado Francisco de Assis Pimenta, pioneiro da ourivesaria diamantinense, vendeu as máquinas e ferramentas que este possuíra para dois outros ourives, Leonel Tolentino Monteiro Júnior e Luiz de Siqueira, antigos aprendizes de Pimenta, pela quantia de um conto e trezentos mil réis - 56,67 libras esterlinas (Livro de Notas n. 36, Cartório do $2^{\circ}$ Ofício, maço 161, p. 30-31. BAT).

\section{A “RIQUEZA ANTIGA" E A "RIQUEZA NOVA" NA DIAMANTINA DE FIN DE SIÉCLE}

No dia 6 de março de 1938, nas comemorações dos cem anos de Diamantina, o Dr. Pedro da Mata Machado pronunciou discurso no qual exaltou o papel desempenhado por uma reduzida lista de pessoas, que ele chamou de "industriais", no desenvolvi-

4 Para uma crônica ainda que com lacunas da tendência de alta dos preços dos diamantes no período 1905-1920, pode-se consultar a matéria do jornal O Momento, de 15 de janeiro de 1992, comemorativa do valor das riquezas e possibilidades econômicas de Diamantina. Hemeroteca da BAT. Gaveta 06, maço 91 . 
mento do município: os Felício dos Santos, os Mata Machado, os Neves, os Alves, os Albinos e os Motta (Voz de Diamantina, 6 de março de 1938, p. 3). O interesse do discurso de Pedro Mata Machado reside em sua tentativa de identificar os homens de fortuna que, na virada do século 19 para o século 20, aproveitaram a crise da mineração para lançar "novas combinações" (SCHUMPETER, 1997, p. 77) e romper com a senda tradicional da economia regional. Para Schumpeter, o desenvolvimento econômico é a realização de novas combinações de forças e materiais, de modo que consiste "primeiramente em empregar recursos diferentes de uma maneira diferente, em fazer coisas novas com elas" (Ibidem, p.78). As novas combinaçôes são "corporificadas (...) em empresas novas que gevalmente não surgem das antigas, mas começam a produzir a seu lado" (Ibidem, p. 77).

Mesmo sob a pressão da queda dos preços das gemas no período das décadas 18701890, a maioria dos homens de fortuna do município de Diamantina jamais se afastou do "fluxo circular" da economia regional, dedicando-se a atividades tradicionais e acumulando "riqueza antiga" (MELLO, 1990) - terras de cultura e de pastagem, lotes diamantinos, casas de comércio e estoques de mercadorias, escravos e dinheiro sonante ou na forma de dívidas de terceiros. Homens como Rodrigo de Souza Reis, Alexandre Gomes da Silva Chaves, José Ferreira de A. Brant e João Pio Fernandes foram típicos mineradores, proprietários de lavras e de escravos, cuja riqueza advinha do comércio de diamantes e do empréstimo de dinheiro a juros. Entre os grandes mineradores surgiu, vez ou outra, indivíduo como o comendador Serafim Moreira da Silva, que aplicou pequena parte de sua fortuna em uma pequena lapidação e em uma pequena cervejaria. Ou pessoa como Anselmo Pereira de Andrade, que fez algum investimento em uma serraria a vapor, uma olaria e uma firma de construção civil (MARTINS, 2004).

Outros homens de fortuna da cidade, como Manoel Cezar Pereira da Silva, Antônio Eulálio de Souza e Franklin de Carvalho, dedicaram sua vida ativa ao comércio, dirigindo estabelecimentos de porte expressivo, que chegaram a ter filiais em lugares distantes de Diamantina. Adicionalmente, eles exploraram lavras, geralmente em sociedade com outros indivíduos. Entre estes negociantes houve mesmo homens como João Francisco da Motta e José Neto Motta, que transformaram uma pequena firma varejista numa grande loja com seções diversas: a Casa Motta \& Cia., conhecida como o "grande empório do Norte". Embora possuíssem pequenas quantias aplicadas em ações de indústrias da região, a "vocação" destes homens não se afastou do trabalho mercantil, do comércio de "exportação/importação" e da operação informal como casa bancária (MARTINS, 2004, p. 195-202).

No período entre as décadas de 1870 e 1890, convivendo com os homens detentores da "riqueza antiga", existiu em Diamantina um punhado de proprietários que cami- 
nhou no sentido de ocupar-se mais com a aplicação e o rendimento do capital do que com o dia-a-dia da administração de fazendas, lavras e estabelecimentos comerciais. Pessoas dotadas de caráter empreendedor, que fundaram negócios mais modernos e passaram a ser detentores de "riqueza nova", baseada na posse de ativos como ações e títulos da dívida pública. No diminuto rol de empresários diamantinenses, destacaram-se os irmãos João, Álvaro e Pedro da Mata Machado, Antônio e Joaquim Felício dos Santos, Josefino Vieira Machado (Barão de Guaicuí), Francisco Joaquim de Menezes (Barão de Araçuaí), Antônio Moreira da Costa (Barão de Paraúna) e Quintiliano Alves Ferreira (Barão de São Roberto).

Como não dispomos de espaço neste trabalho para tratar dos empreendimentos de todos eles, faremos rápida descrição da carreira dos que são menos conhecidos fora dos limites do antigo município de Diamantina, ao contrário dos irmãos Mata Machado e Felício dos Santos, bastante afamados no Rio de Janeiro e em Minas Gerais.

O Barão de Araçuaí, Francisco Joaquim de Menezes, possuía em 1867, ano de seu falecimento, uma das maiores fortunas da região, estimada em 304:413\$719 (13.565,67 libras esterlinas), composta por: dinheiro em notas correntes, 32:674\$220 (9,8\% do total); jóias, 1:284\$720 (0,4\%); escravos, 15:400\$000 (4,6\%); bens de raiz, 31:000\$000 (9,3\%); dívidas ativas, 87:654\$779 (26,4\%) e ações e apólices da dívida pública, 136:400\$000 (41,1\%). Entre as ações que o Barão de Araçuaí possuía, havia 280 ações do Banco do Brasil, cotadas em 51:800\$000, ações da Companhia União e Indústria, fundada por Mariano Procópio em Juiz de Fora, e ações da Companhia do Mucuri, fundada por Teófilo Otoni, para as quais não havia avaliação no inventário (Inventário do Barão de Araçuaí, 1867, Cartório do $1^{\circ}$ Ofício, maço 11. BAT). A participação do Barão de Araçuaí nestas empresas sugere que ele havia compreendido que novos processos estavam em curso na economia brasileira, modificando seu perfil. Sua fortuna estava em transição, num movimento de substituição de terras e escravos por ativos novos (ações de empresas e apólices da dívida pública).

Josefino Vieira Machado, cuja fortuna havia sido formada no comércio de diamantes, em sociedade com Antônio Felício dos Santos, aproveitou a crise da mineração para iniciar novas atividades, nas quais aplicou toda a sua riqueza. O Barão de Guaicuí dedicou-se ao ramo da navegação fluvial e da implantação de novas lavouras nas terras banhadas pelo Rio das Velhas. Em 1878, ele e o Dr. Aurélio A. Pires de Figueiredo firmaram contrato com o governo mineiro para a navegação no São Francisco e afluentes. Os contratantes aceitaram o navio Saldanha Marinho com a subvenção de 9:800\$000 para os reparos no vapor e custeio da empresa. A condição exigida pelo governo era a de serem realizadas seis viagens redondas (ida e volta) 
por ano, desde Guaicuí até a Cachoeira do Sobradinho, num percurso de 250 léguas (Relatório apresentado à Assembléia Legislativa pelo Presidente da Província, em 15 de outubro de 1879). Os barcos da empresa navegaram até Santo Hipólito, no baixo curso do Rio das Velhas. Para favorecer a própria empresa de navegação, o Barão de Guaicuí instalou fazendas nas margens do Rio das Velhas, iniciando lavouras de café, algodão, cana-de-açúcar e a instalação de serrarias para a exploração de áreas florestais. Vítima do impaludismo, contraído em Santo Hipólito, Josefino Vieira Machado morreu no final de 1879 , com a fortuna exaurida na tentativa de desenvolver a empresa.

O Barão de Paraúna, Antônio Moreira da Costa, filho natural de Ana Sabina de Lacerda, angariou fortuna nos negócios minerais, tornando-se um dos homens mais ricos de todo o norte de Minas. Seu inventário foi concluído em 1898 (Inventário do Barão de Paraúna, 1898, Cartório do $1^{\circ}$ Ofício, maço 12 B. BAT). Conforme o referido documento, o Barão de Paraúna possuía riqueza avaliada em cerca de 328:652\$000 (45.710 libras esterlinas), composta pelos seguintes ativos: bens de raiz, 13:600\$000 (4,1\% do total); móveis e semoventes, 2:097\$550 (0,64\%); diamantes, 8:089\$000 (2,5\%); ações e letras firmadas por empresas, 256:743\$159 $(78,1 \%)$ e dívidas ativas, 8:823\$050 (2,7\%). O Barão de Paraúna havia sido a única pessoa não integrante da família Mata Machado que participou como sócio na fundação da Fábrica de Tecidos Santa Bárbara, com o capital de trinta contos de réis. A Tabela 4 abaixo apresenta a relação de letras firmadas com empresas e de participações acionárias do Barão de Paraúna: 


\section{TABELA 4 - AÇÕES E LETRAS DO BAR ÃO DE PARAÚNA - ANO 1898}

\begin{tabular}{llr}
\hline Ativos & \multicolumn{1}{c}{ Empresas } & \multicolumn{1}{c}{ Valores } \\
\hline & Fábrica de Tecidos de Itinga & $14: 000 \$ 000$ \\
& Banco de Minas Gerais & $4: 000 \$ 000$ \\
Ações & Fábrica da Conceição do Rio Manso & $15: 000 \$ 000$ \\
& Cia. Industrial Rio Pretana & $4: 800 \$ 000$ \\
& Cia. Chapelaria Norte de Minas & $200 \$ 000$ \\
& Cia. Mineração do Paraúna & $800 \$ 000$ \\
& Cia. Promotora de Indústrias e Melhoramentos & $100 \$ 000$ \\
& & \\
& Luiz de Rezende \& Cia. & $164: 298 \$ 810$ \\
& Oliveira Neves \& Cia. & $15: 343 \$ 144$ \\
& Companhia Industrial Biribiri & $30: 000 \$ 000$ \\
& Cia. Indústria e Comércio Norte de Minas & $7: 801 \$ 205$ \\
\hline
\end{tabular}

Fonte: Inventário do Barão de Paraúna, 1898, Cartório do $1^{\circ}$ Ofício, maço 12 B. BAT.

Sem se afastar da mineração e do comércio de diamantes, o Barão de Paraúna investiu uma enorme parte de sua fortuna em ações e letras de fábricas de tecidos fundadas no norte de Minas Gerais. Seus rendimentos, no fim de sua carreira como homem de negócios, eram formados por juros e dividendos sobre a aplicação de capital. O Barão de Paraúna não possuía terras e, em Diamantina, era dono de apenas três imóveis.

Outro pioneiro da indústria têxtil, da chapelaria a vapor e da indústria da lapidação de diamantes foi o Barão de São Roberto, Quintiliano Alves Ferreira. Entre os anos de 1887, quando empregou quinze contos de réis na criação da fábrica de fiação e tecidos no Arraial de Gouveia, e o ano de 1895, data de seu falecimento, o Barão de São Roberto dedicou-se à administração desta fábrica e da lapidação Vitória Augusta. No total de sua fortuna - avaliada em 85:405\$000 ou 8.592 libras esterlinas -, as apólices da dívida pública representavam 20:000\$000 (23,4\% do total) e a letra de câmbio firmada com a Fábrica de Tecidos São Roberto alcançava o valor de 27:000\$000 (31,6\%). Quintiliano Alves Ferreira vivia, às vésperas de seu falecimento, dos rendimentos auferidos como diretor de fábrica e dos juros e dividendos decorrentes de seus investimentos nas empresas que ajudara a criar (Inventário de Quintiliano Alves Ferreira, 1895, Cartório do $2^{\circ}$ Ofício, maço 101. BAT).

A trajetória destes homens de negócio mais modernos é sinal de que ocorreu um processo de empresariamento no âmbito de algumas famílias diamantinenses. A marcha deste processo foi marcada pela presença de diversas racionalidades: a preservação do envolvimento com a mineração de diamantes, que alimentava o capital mercantil e 
supria as indústrias; o acúmulo e a manutenção de propriedades urbanas e de títulos da dívida pública, o que permitia o aval para a obtenção de crédito e a preservação da própria unidade familiar como centro da articulação dos interesses econômicos; o efetivo ingresso no setor produtivo industrial, que abriu possibilidades de aproveitamento de matérias-primas regionais; o emprego de recursos tecnológicos disponíveis no País na época, para a operação dos empreendimentos industriais; a utilização moderna do crédito - fornecido por bancos do Rio de Janeiro e de Juiz de Fora - para fins industriais, fazendo as empresas "cavalgarem sobre suas dívidas".

Estes poucos empresários diamantinenses conseguiram realizar, na virada do século 19 para o século 20, as "combinações novas" de que falava Schumpeter. Por conseguinte, eles dinamizaram em medida não desprezível a economia no Alto Jequitinhonha e trouxeram a esperança do "progresso" e da "civilização" para as populações urbanas de Diamantina.

\section{PROJETOS REGIONAIS DE DESENVOLVIMENTO ECONÔMICO}

Ao estimular algumas famílias de Diamantina a construir novos tipos de negócios, a crise da mineração no período 1870-1890 contribuiu para a maior diferenciação de setores econômicos no Alto Jequitinhonha, processo que resultou, também, na clivagem de interesses no seio das elites regionais. Gradualmente, os pontos de vista e os projetos dos detentores da "riqueza antiga" e dos possuidores da "riqueza nova" assumiram contornos distintos. Levadas para as redações dos jornais da cidade, estas diferentes visões da região e de seu futuro econômico tornaram-se assunto de debate na opinião pública regional.

Um projeto influente de desenvolvimento regional surgiu ao redor dos integrantes da família Felício dos Santos, a partir dos anos 1860. O principal formulador deste projeto foi o Dr. Joaquim Felício dos Santos, pessoa de múltiplos afazeres e interesses: político, advogado, jornalista, professor, industrial, escritor e jurisconsulto. As bases do projeto, inspirado no ideal "liberal-republicano", ficaram expostas nas Memórias do Distrito Diamantino, que vieram a público numa série de artigos no jornal $O$ Jequitinhonha em 1862. O projeto de Joaquim Felício comportava reformas político-institucionais e iniciativas econômicas.

As Memórias afirmavam a necessidade de, no campo político, o País combater: a) a centralização administrativa, buscando novo equilíbrio entre o que chamava de "governo representativo" e de "atividade local"; b) os monopólios econômicos e a excessiva intervenção estatal, de modo a libertar a iniciativa privada; c) o domínio dos cargos representativos pelas poderosas oligarquias, para o que deveria ser ado- 
tado o sufrágio direto e generalizado; d) a corrupção dos funcionários públicos e; e) a prática dos casuísmos, comum entre os governos na história do País. No plano econômico, as Memórias preconizavam: a) a reforma completa dos impostos, que deveriam ser gerais e proporcionais às posses de cada um; b) o investimento na preparação profissional dos trabalhadores, incluindo os mineradores e os agricultores; c) a adoção, o domínio e o desenvolvimento de tecnologias para aumentar a eficiência e os lucros na economia; d) a promoção da diversificação da base produtiva na região e; e) o apoio regional decidido aos setores industriais têxtil e siderúrgico.

A ênfase na indústria é retomada por Antônio Felício dos Santos, quando da publicação do Manifesto da Associação Industrial, no ano de 1881 (BONAVIDES ; AMARAL, 2002, p.723-726, v. 2). Antônio Felício dos Santos foi o primeiro presidente desta associação nacional, sediada no Rio de Janeiro. O referido Manifesto principiava pela crítica do livre-cambismo e da voragem fiscal do governo. Sua preocupação central era a de derrotar a idéia de que o Brasil estaria fadado a ser exclusivamente agrícola e apelava aos dirigentes nacionais para que criassem ambiente propício para a cultura industrial. Para tanto, seria preciso adotar o regime protetor da indústria, moralizar as classes pobres pelo trabalho e pela educação industrial, atrair e assimilar imigração perene de operários e pequenos capitalistas, favorecer o desenvolvimento das cidades.

O projeto de desenvolvimento regional proposto pelos irmãos Felício dos Santos era industrialista, de base urbana, preocupado essencialmente com a diversificação da produção econômica, pois considerava terríveis as consequiências que resultavam das baixas no valor ou na produção do quase exclusivo gênero de exportação brasileiro - o café -, ou regional - o diamante. Também exigia a renovação completa das práticas políticas e a transformação social, que "reponbam a pirâmide social em equilíbrio estável, apoiando-se sobre a base e não sobre o vértice".

Outro projeto para o desenvolvimento regional surgiu da experiência adquirida pela família Mata Machado com empreendimentos agrícolas, de navegação fluvial, curtumes e produção de charque, indústria vinícola e fábrica de tecidos. O principal formulador desta segunda proposta foi o Dr. Pedro da Mata Machado (1865-1944): promotor de justiça, político, professor, industrial. As linhas mestras do projeto foram lançadas na carta distribuída aos eleitores do $6^{\circ}$ Distrito de Minas Gerais, em outubro de 1894 (O Dr. Pedro da Mata Machado ao corpo eleitoral do $6^{\circ}$ Distrito de Minas Gerais. Diamantina: Oficinas Tipográficas da Cidade Diamantina, 1894. BAT). Neste documento, o então candidato ao Senado estadual elencou as prioridades que norteariam sua ação política: educação profissional, acesso facilitado ao crédito, imigração, transporte ferroviário e agilização da Justiça. 
No campo da educação escolar, Pedro da Mata Machado pleiteava o fortalecimento do ensino primário e a criação de uma rede de escolas profissionais, que difundiriam os "métodos científicos da agricultura e da criação". Estes institutos profissionais e técnicos facilitariam o aproveitamento das imensas riquezas naturais do norte de Minas. Para enfrentar o problema da falta de crédito, que impedia o crescimento dos agricultores e pecuaristas, Pedro da Mata Machado sugeria "a criação de pequenos bancos que facilitem o crédito e a aquisição de instrumentos indispensáveis à lavoura" (Ibidem, p. 7-8). Propunha ainda, para acelerar a modernização da agropecuária regional, a "urgente e indispensável promoção da imigração facilitada pelo Estado" (Ibidem, p. 8). Os meios de transporte também teriam que ser melhorados no norte de Minas, com o desenvolvimento da viação férrea e fluvial. Por fim, a economia regional necessitava da agilização da Justiça porque os negócios não poderiam prosperar num ambiente em que as pendências só são resolvidas a muito longo prazo. O futuro senador comprometia-se a lutar pela criação de novas Relações (tribunais de segunda instância) no norte e no sul do Estado.

O programa do Dr. Pedro da Mata Machado, exposto nos jornais A Idea nova e Cidade de Diamantina, era francamente agrarista e criticava de forma aberta a industrialização brasileira. Ele dizia que a República repetia o erro do Império, ao prosseguir "na cópia servil das brilhantes civilizaçôes industriais". Segundo o parlamentar diamantinense, a República agravava os problemas econômicos e sociais brasileiros ao procurar

criar, por meio de tarifas proibitivas, a nação industrial. O protecionismo que copiamos, hipertrofiando-o, teve êxito relativo na América do Norte e em algumas nações da Europa porque esses países reuniam condiçôes do estádio industrial - densidade de população, acúmulo de capitais, abundância de matéria-prima, facilidade de transporte, largo consumo - e possuiam já uma indústria própria. A esse organismo, naturalmente criado, foi que a tarifa procurou beneficiar. Esta não faz o milagre de transformar uma nação agricola em industrial, mas tem o funestissimo poder de obstar o surto natural da agricultura e de aniquilar as indústrias legitimas, coetâneas do período agrícola. Absorvendo grandes capitais e impondo enormes sacrificios ao consumidor, as induistrias ficticias elevam artificialmente os salários e os capitais circulantes, e desviam os recursos destinados à lavoura, à pecuária, à fiação e tecelagem e indústrias congêneres que desabrocham com a agricultura (Civilização artificial, obra dedicada ao Ex. Sr. Dr. Wenceslau Braz. Belo Horizonte: Imprensa Oficial do Estado de Minas Gerais, 1914. p. 6-7. BAT). 
As idéias do Dr. Pedro da Mata Machado relativas à promoção do desenvolvimento regional eram afinadas com as diretrizes produzidas pelo Congresso Agrícola, Industrial e Comercial de 1904, comandado por João Pinheiro da Silva, de quem o político diamantinense era afilhado. Como sabemos, a ênfase na diversificação e modernização da agropecuária mineira foi o centro da ação governamental nas primeiras décadas do século 20 (DULCI, 1999).

A despeito das diferenças - indústria $\mathrm{x}$ agricultura, protecionismo $\mathrm{x}$ livre-cambismo, trabalhador nacional $\mathrm{x}$ imigrante, radicalismo republicano $\mathrm{x}$ elitismo benevolente -, os projetos dos Felício dos Santos e dos Mata Machado convergiam em muitos aspectos. Os dois grupos queriam a consolidação de uma sociedade republicana, liberal, definitivamente desvencilhada dos privilégios aristocráticos que marcaram o passado escravista. Ambos ansiavam pela inovação, cultuavam a figura emblemática do self made man, preconizavam a modernização de Diamantina.

Os dois projetos de desenvolvimento regional insistiam na necessidade de racionalizar a produção e o trabalho, para o que deveria ser combinada a concessão de benefícios para os trabalhadores com a propaganda (ideológica e política), visando basear toda a vida do País na produção. Tanto na Fábrica de Tecidos de Biribiri (da família Felício dos Santos) quanto na Fábrica de Tecidos Santa Bárbara (da família Mata Machado) os operários ficaram submetidos a um regime disciplinado por regulamento específico e detalhado, que previa prêmios, gratificações, fundo de beneficência para inválidos e velhos e até mesmo a co-participação dos operários nos lucros. Havia a preocupação comum com o controle da "moralidade" dos operários e a preferência por um quadro de trabalhadores estável e permanentemente afinado. Os Felício dos Santos e os Mata Machado desejavam forjar novos homens, novos trabalhadores, para atuar nas fábricas e nas fazendas da região norte-mineira. Os dois projetos de desenvolvimento regional partiam de uma mesma premissa política: a vigência do Estado Liberal, o fortalecimento e a defesa da livre iniciativa e do individualismo econômico. Neles, era evidente a admiração pelos Estados Unidos da América, suas instituições políticas, sociais e econômicas. Daí a crítica aos "setores parasitários" - como por exemplo, os atravessadores, os rentistas urbanos e os profissionais da política - que ambos os projetos continham, sendo bem maior a veemência desta crítica nos discursos de Joaquim Felício dos Santos.

Os pontos convergentes que assinalamos indicam a presença, em setores significativos da camada dos homens de negócio diamantinenses, de uma vontade de criar determinado ambiente, determinada estrutura social e determinado tipo de Estado que acelerassem os processos de mudança que o País vivia na passagem do século 19 para o século 20, favoráveis à modernização capitalista em curso. Havia em Diamantina, portanto, um impulso americanista (GRAMSCI, 1988) que dava forma 
aos sonhos e orientava os negócios e a ação política de uma parte dos homens de fortuna do município. ${ }^{5}$

Os integrantes mais inquietos das elites diamantinenses dividiram-se entre os dois projetos, o que favoreceu a inércia da maioria dos homens de negócio locais, acostumados ao modo tradicional de fazer as coisas. Os detentores da "riqueza antiga" eram muito mais numerosos do que o punhado de homens com tino empresarial que Diamantina gerou na virada do século 19 para o século 20 . O fracasso da maioria das empresas industriais e de serviços (transportes e casas bancárias) que mobilizaram a energia dos Felício dos Santos, dos Mata Machado, dos Barões de Paraúna e São Roberto e do Coronel José Neves Sobrinho, visível na primeira década do Novecentos, trouxe água para o moinho dos homens de negócio tradicionais da região, que preferiam a adaptação gradual às mudanças infinitesimais do "fluxo circular" da economia regional, aos riscos de "conduzir os meios de produção para novos canais". Por outro lado, a melhora do mercado do diamante, com a entrada dos compradores norte-americanos e os investimentos das companhias estrangeiras (a partir de 1897), bem como o início do processo de semimecanização do garimpo nos anos 1920, abriram boas perspectivas para os grandes mineradores e diamantários.

Assim, logo após a Primeira Guerra, Diamantina evocava as observações feitas por Gramsci (1988, p. 378-382) sobre o chamado "mistério de Nápoles": como era possível existirem grandes cidades na Itália (e em outras partes da Europa) praticamente sem indústrias, nas quais parcelas numerosas da população viviam desempregadas ou desvinculadas da produção de novos bens? A cidade de Diamantina voltara a ser o local de moradia de proprietários de terras minerais que nela gastaram a renda que auferiram de seus garimpos, e de milhares de funcionários públicos e eclesiásticos que, com seus salários regulares, movimentaram a venda de mercadorias e serviços, para cuja oferta havia uma pulverizada rede de pequenos estabelecimentos diversos. Em torno destas camadas, sobreviveram milhares de pessoas ligadas aos trabalhos domésticos, às indústrias artesanais, ao comércio ambulante e às ações de caridade. Outra parte da cidade, que recebera a ferrovia em 1914, organizara-se em torno do atendimento aos viajantes e do comércio atacadista, cujos estabelecimentos perdiam rapidamente a dimensão e as pretensões hegemônicas do passado, ocupando-se apenas com o abastecimento de vendeiros que atuavam nos distritos e nas pequenas cidades vizinhas.

5 Para Gramsci, o americanismo compreendia o desenvolvimento, nos Estados Unidos, de uma sociedade baseada na atividade industrial, com formas moderníssimas de produção, racionalização da produção e do trabalho, sem a presença de grupos sociais "parasitários" (massas de mandrióes e inúteis), vivendo num ambiente de livre iniciativa e individualismo econômico, nos quadros institucionais-legais do Estado Liberal. 
A Diamantina, que os Felício dos Santos e os Mata Machado desejaram ver como o coração industrial, comercial e educacional do norte mineiro, correspondia bem, no pós-1930, ao ditado popular que Gramsci usou para caracterizar a população de cidades italianas como Nápoles: "quando um cavalo caga, cem pássaros jantam”.

\section{REFERENNCIAS}

ABREU, M. D. A ordem do progresso. Rio de Janeiro: Campus, 1990.

BONAVIDES, Paulo; AMARAL, Roberto. Textos políticos da história do Brasil. $3^{\mathrm{a}} \mathrm{ed}$. Brasília: Senado Federal, 2002. v. II

DULCI, Otávio Soares. Política e recuperação econômica em Minas Gerais. Belo Horizonte: Editora UFMG, 1999.

GRAMSCI, Antonio. Americanismo e fordismo. In: Maquiavel, a politica e o estado moderno. $6^{a}$ ed. Rio de Janeiro: Civilização Brasileira, 1988.

IBGE. Anuário estatístico do Brasil, Ano V. Rio de Janeiro: IBGE, 1939-40.

MARTINS, Marcos Lobato. Identidades sociais e ação coletiva: o caso dos garimpeiros da microrregião de Diamantina. 1997. Dissertação (Mestrado), FAFICH/ UFMG. Belo Horizonte.

. Os negócios do diamante e os homens de fortuna na praça de diamantina, $M G$ : 1870-1930. 2004. Tese (Doutorado), FFLCH/USP. São Paulo.

MARTINS, Roberto Borges. Minas e o tráfico de escravos no século XIX, outra vez. In: SZMRECSÁNYI, Tamás; LAPA, José Roberto Amaral (orgs.). História econômica da Independência e do Império. $2^{a}$ ed. São Paulo: Hucitec/ Edusp/ Imprensa Oficial, 2002.

MELLO, Zélia Cardoso de. Metamorfoses da riqueza - São Paulo, 1845-1895. $2^{\mathrm{a}} \mathrm{ed}$. São Paulo: Hucitec, 1990.

OLIVEIRA, Maria Teresa Ribeiro de. Indústria têxtil mineira do século XIX. In: SILVA, Sérgio; SZMRECSÁNYI, Tamás (orgs.). História econômica da Primeira Repuiblica. 2a ed. São Paulo: Hucitec/ Edusp/ Imprensa Oficial, 2002.

SANTOS, Joaquim Felício dos. Memórias do Distrito Diamantino. $5^{\mathrm{a}}$ ed. Petrópolis: Vozes, 1978.

SCHUMPETER, Joseph A. Teoria do desenvolvimento econômico. São Paulo: Nova Cultural, 1997. (Coleção Os Economistas)

SOUZA, José Moreira de. Cidade: momentos e processos. Serro e Diamantina na formação do Norte mineiro no século XIX. São Paulo: ANPOCS/Marco Zero, 1993. 